\title{
"BENTHIK" TRADITIONAL GAME TO IMPROVE THE ABILITY OF ADDITION NUMBER
}

\section{Rafika Said, Suyanto}

Universitas Sebelas Maret

rafikasaid85@gmail.com

\section{Article History}

accepted 09/07/2018

approved 01/08/2018

published 17/09/2018

\section{Keywords}

permainan tradisional, benthik, matematika, penjumlahan

\begin{abstract}
Permainan tradisional merupakan peermainan yang menyenangkan sekaligus membantu dalam proses pembelajaran .Benthik merupakan salah satu permainan tradisional yang sudah sangat dikenal di Indonesia. Permainan tradisional benthik dapat digunakan untuk membantu proses pembelajaran matematika pada operasi hitung penjumlahan bilangan cacah. Matematika yang bersifat abstrak menjadi salah satu penyebab siswa-siswa pada jenjang pendidikan dasar mengalami kesulitan dalam belajarnya. Pembelajaran matematika yang abstrak menyebabkan siswa $S D$ yang berada pada tahap berfikir konkret memerlukan suasana yang menyenangkan dan juga media yang dapat memperjelas apa yang akan disampaikan oleh guru. Metode yang digunakan dalam penelitian ini adalah metode documenter. Permainan tradisional benthik bisa menjadi referensi guru dalam meningkatkan ketrampilan operasi hitung penjumlahan bilangan cacah pada mata pelajaran matematika kelas III SD.
\end{abstract}

Social, Humanities, and Education Studies (SHEs): Conference Series

p-ISSN 2620-9284 https://jurnal.uns.ac.id/shes

e-ISSN 2620-9292 


\section{PENDAHULUAN}

Pembelajaran matematika merupakan mata pelajaran yang ditakuti oleh siswa, bahkan oleh orang dewasa. Konsep-konsep matematika merupakan konsep yang abstrak, sementara pola pikir siswa SD (sekolah dasar), menurut Piaget masih pada tahap operasi konkrit. Siswa perlu diupayakan untuk memahami matematika sesuai dengan tingkat perkembangan mentalnya, guru juga diharapkan menciptakan suasana pembelajaran yang menyenangkan. Matematika merupakan mata pelajaran yang selama ini dianggap tidak menyenangkan bagi siswa. Hal tersebut muncul karena berbagai hal, antara lain: guru kurang memberi motivasi pada siswa untuk menyukai pelajaran matematika, metode dan media yang digunakan guru kurang bervariasi. Dalam hal ini seorang guru betul-betul harus kreatif dan inovatif dalam menciptakan pembelajaran yang menyenangkan.

Menurut Somakin(2008) Bermain merupakan salah satu ciri anak usia SD yang dapat berinteraksi langsung dengan lingkungan. Dengan menginteraksikan permainan ke dalam proses pembelajaran, berarti turut mengkondisikan siswa belajar sambil bermain sehingga siswa menjadi aktif dan senang dalam belajar. Mengenai permainan pada anak-anak tingkat SD, Fosnot \& Maarten Dolk (2001) menyatakan bahwa children of all ages, across all cultures, love to play games. Board games, card games, and dice games provide rich contexts for mathematical learning. Games can also be made that will bring certain mathematical ideas to the surface for exploration. Anakanak dari segala usia suka bermain game. Permainan papan, permainan kartu, dan permainan dadu menyediakan konteks yang kaya untuk belajar matematika. Games juga dapat dibuat untuk mengeksplor ide-ide matematika tertentu ke permukaan.

Mengingat pentingnya permainan dalam proses pembelajaran, maka perlu dieksplorasi lebih jauh khasanah permainan yang mampu menjadi media pembelajaran. Salah satu permainan yang perlu digali lebih jauh adalah permainan tradisional di Indonesia yang menunjang pembelajaran terutama pada mata pelajaran matematika. Jenis permainan tradisional yang dapat dimanfaatkan sebagai konteks belajar penjumlahan bilangan cacah adalah permainan tradisional benthik. Permainan tradisional benthik mengharuskan para pemain menghitung dan menjumlah untuk menentukan poinatau nilai yang diperolehnya. Permainan ini sangat terkenal dikalangan anak-anak di seluruh wilayah Indonesia dengan penyebutan nama yang berbeda-beda pada setiap daerah. Permainan ini merupakan alternatif menarik yang dapat digunakan untuk meningkatkan ketrampilan siswa dalam belajar matematika pada materi penjumlahan bilangan cacah pada kelas III SD.

\section{METODE}

Penelitian ini menggunakan desain deskriptif kualitatif. Artinya, hasil penelitian dipaparkan untuk menggambarkan kualitasnya. Sumber data dalam penelitian ini berupa permainan tradisional benthik untuk meningkatkan ketrampilan penjumlahan bilangan cacah. Untuk mendapatkan data yang diperlukan peneliti menggunakan teknik pengumulan data baca-catat. Sumber data tersebut dibaca berulang-ulang secara intens dan cermat untuk mendapatkan data yang sesuai dengan tujuan penelitian. Kemudian, data yang telah ditemukan direkam dalam wujud catatan. Dalam mencari data peneliti menetapkan instrumennya adalah peneliti sendiri. Sedangkan, teknik analisis data yang digunakan dalam penelitian ini adalah teknik analisis isi. Maksudnya, peneliti menganalisis data yang telah terkumpul untuk menemukan makna yang terkandung di dalamnya sesuai dengan tujuan penelitian.

\section{PEMBAHASAN}

Menguatnya arus globalisasi di Indonesia membawa pola kehidupan dan hiburan baru yang mau tidak mau memberikan dampak tertentu terhadap kehidupan sosial dan budaya masyarakat Indonesia, termasuk di dalamnya kelestarian permainan 
tradisional anak-anak. "Permainan " adalah: (1) Sesuatu yang dipergunakan untuk bermain, barang atau sesuatu yang di permainkan. (2) Hal bermain, perbuatan bermain ( W.J.S. Poerwadarminta.1984 ). Mayesty dalam Sujiono Sujiono (2010:34) menyatakan bahwa bagi seorang anak, bermain adalah kegiatan yang mereka lakukan sepanjang hari karena bagi anak bermain adalah hidup dan hidup adalah permainan.

Arif S. Sadiman (2009: 75) mengatakan bahwa permainan (games) adalah setiap kontes antara para pemain yang berinteraksi satu sama lain dengan mengikuti aturanaturan tertentu untuk mencapai tujuan-tujuan tertentu pula. Pendapat senada juga disampaikan oleh Santrock (2007: 220) yang mengatakan bahwa games adalah aktivitas yang dilakukan demi kesenangan dan memiliki peraturan. Santrock (2007: 216) mengatakan bahwa sebagian besar waktu anak-anak, terutama anak kecil, berinteraksi dengan sebaya mereka, merupakan waktu bermain. Hal tersebut mengandung makna bahwa masa anak-anak adalah masa dimana anak-anak akan menghabiskan sebagian besar waktunya untuk bermain. Jadi masa anak-anak seolah tidak dapat dipisahkan dari aktivitas bermain. Daniel Berlyne (dalam Santrock, 2007: 217) menggambarkan bahwa permainan sebagai aktivitas yang seru dan menyenangkan karena permainan memuaskan dorongan bereksplorasi yang kita semua miliki.

Menurut Andriani (2012:135) salah satu cara untuk meningkatkan potensi anak di usia dini adalah dengan cara bermain menggunakan permainan tradisional.

Menurut Sukirman (2008:29) mengatakan bahwa permainan tradisional anak merupakan unsur-unsur kebudayaan yang tidak dapat dianggap remeh, karena permainan tradisional memberikan pengaruh yang tidak kecil terhadap perkembangan kejiwaan, sifat, dan kehidupan sosial dikemudian hari. Selain pengertian tersebut, masih ada perspektif tentang permainan tradisional yaitu perspektif fungsional, permainan, psikologis, adaptasi.

1. Perspektif Fungsional: Bermain sebagai upaya mempersiapkan diri menjadi orang dewasa.

Pelopor teori fungsionalisme adalah Bronislaw Malinowski, ahli antropologi. Dia menyatakan bahwa permainan perlu diketahui nilai pendidikannya, dan lebih dari itu juga hubungannya dengan fungsinya untuk "preparation for economic skills". Pembekalan keterampilan-keterampilan ekonomi (Sukirman, 2008:21). Berbagai permainan anak, misalnya "pasaran", "dokter-dokteran", "sekolah-sekolahan" dan sebagainya, yang biasa disebut "role play" (bermain peran), merupakan contoh dari permainan tradisional yang mempunyai fungsi mempersiapkan anak-anak untuk memainkan peran yang sebenarnya ketika mereka dewasa nanti. Permainan seperti ini juga merupakan sebagian dari kondisi-kondisi yang memungkinkan si anak melakukan "objectivication the self". Melalui kegiatan bermain anak-anak akan dapat membayangkan dirinya berada dalam berbagai kedudukan dan peran, dan dengan demikian anak-anak akan dapat membangun karakternya sebagai persiapan menjadi orang dewasa. Dalam bermain, seorang anak harus memperhatikan anak-anak lain yang berbeda perannya, tetapi berinteraksi dengannya (Sukirman, 2008:21).

2. Perspektif Bermain: Bermain Sebagai Permainan.

Kajian tentang permainan anak dengan perspektif permainan banyak dikerjakan oleh ahli folklor di akhir abad 19. Hasilnya lebih banyak bersifat deskriptif. Para ahli ini hanya menggambarkan jenis-jenis permainan yang ada dengan berbagai macam peralatannya, sedang proses sosial dari permainan itu sendiri banyak yang terlupakan. Para ahli juga beranggapan bahwa game (permainan) adalah wujud yang paling jelas dari bermain.

3. Perspektif Psikologis: Bermain Sebagai Wujud Kecemasan dan Kemarahan. 
R.R Eiferman mencoba mengetahui perbedaan sifat anak di desa dengan anakanak di kota dengan memperhatikan permainan yang ada di kalangan mereka. Hipotesanya mengatakan bahwa anak-anak pedesaan memiliki lebih banyak kesempatan untuk terlibat dalam dunia orang dewasa dibandingkan dengan anakanak kota. Hal tersebut berdampak anak-anak pedesaan tidak akan mengalami konflik yang begitu keras, sehingga mereka juga akan kurang tertarik pada "competitive games" yang dibangun atas dasar konflik, kecemasan, dan kemarahan (Sukirman, 2008:24).

4. Perspektif Adaptasi: Bermain Sebagai peningkatan Kemampuan Beradaptasi.

Ada dua teori yang berhubungan dengan adaptasi makhluk. Teori tersebut adalah teori arousal dan teori educational. Teori arousal menjelaskan fenomena bermain adalam jangka pendek, sedangkan teori educational menjelaskan pemahaman bersifat jangka panjang. Dalam teori arousal dikatakan bahwa setiap anak pada dasarnya mempertahankan "an optimal level of arousal" dan ini berarti bahwa setiap anak menginginkan perubahan. Teori kedua, yaitu teori pendidikan, pada dasarnya tidak jauh berbeda dengan pendekatan fungsional. bermain dapat "serve as an educational medium to exercise and improve the young animal's survival and reproductive skills". Ternyata bermain bukanlah kegiatan yang tidak bermakna, terutama bagi anak-anak. Bermain adalah upaya membekali anak-anak dengan kemampuan tertentu agar dapat bertahan hidup dalam lingkungannya.

Matematika merupakan ilmu universal yang mendasari perkembangan teknologi moderen, mempunyai peran penting dalam berbagai disiplin dan mengembangkan daya pikir manusia. Perkembangan pesat di bidang teknologi informasi dan komunikasi dewasa ini dilandasi oleh perkembangan matematika di bidang teori bilangan, aljabar, analisis, teori peluang dan matematika diskrit.

Mata pelajaran Matematika perlu diberikan kepada semua peserta didik mulai dari sekolah dasar untuk membekali peserta didik dengan kemampuan berpikir logis, analitis, sistematis, kritis, dan kreatif, serta kemampuan bekerjasama. Kompetensi tersebut diperlukan agar peserta didik dapat memiliki kemampuan memperoleh, mengelola, dan memanfaatkan informasi untuk bertahan hidup pada keadaan yang selalu berubah, tidak pasti dan kompetitif. Untuk mencapai hal tersebut disusunlah standar kompetensi dan kompetensi dasar sebagai landasan pembelajaran.

Salah satu standar kompetensi kelas III SD adalah melakukan operasi hitung sampai tiga angka dimana kompetensi dasarnya ada yang berupa penjumlahan sampai tiga angka.

Sri Subarinah (2006: 29) mengemukakan bahwa: "operasi penjumlahan adalah menggabungkan dua kelompok (himpunan). Jika kelompok $A$ yang anggotanya ada 2 anak digabungkan dengan kelompok $B$ yang anggotanya ada 3 orang maka diperoleh kelompok baru, sebut saja kelompok $\mathrm{AB}$. Dengan membilang diperoleh bahwa banyaknya anggota kelompok $A B$ tersebut adalah 5 . Hal ini menjelaskan bahwa $2+3$ $=5$ ".

Mochtar A. Karim (1996: 100) mengemukakan bahwa operasi penjumlahan pada bilangan cacah pada dasarnya merupakan suatu aturan yang mengkaitkan setiap pasangan bilangan dengan suatu bilangan cacah yang lain.

Dalam kaitannya terhadap ketrampilan penjumlahan, Bell (1981: 108) mengemukakan bahwa keterampilan adalah operasi atau prosedur yang diharapkan dapat dikuasai siswa secara cepat dan tepat. Siswa dikatakan menguasai keterampilan apabila ia dapat menunjukkan keterampilan tersebut secara tepat, dapat menyelesaikan berbagai jenis masalah yang memerlukan keterampilan tersebut, dan menerapkan keterampilan tersebut ke dalam berbagai situasi.

Berdasarkan pendapat-pendapat diatas dapat disimpulkan bahwa ketrampilan penjumlahan merupakan kemampuan menyelesaikan penggabungan dua kelompok (himpunan) sesuai prosedur dengan cepat dan tepat. 
Dalam perkembangannya anak usia kelas III SD merupakan usia dimana anak masih suka bermain.

Melalui bermain anak diajak untuk bereksplorasi, menemukan, dan memanfaatkan objek-objek yang dekat dengannya, sehingga pembelajaran menjadi bermakna (Puskur Balitbang, 2002) . Vygotsky (Sofia Hartati. 2005: 15-16) meyakini bahwa bermain mengarahkan perkembangan. Bermain memberikan suatu konteks bagi anak untuk mempraktekan keterampilan-keterampilan yang baru diperoleh dan juga untuk berfungsi pada puncak kemampuan mereka yang berkembang untuk mengambil peranperan sosial baru, mencoba tugas-tugas baru dan menantang, serta memecahkan masalah-masalah yang kompleks. Selain itu untuk mendukung perkembangan kognitif,bermain memerankan fungsi-fungsi penting dalam perkembangan fisik, emosi, dan sosial anak. Anak mengekspresikan dan mengemukakan ide-ide, pikiran, dan perasaan mereka ketika terlibat dalam bermain simbolik. Selama bermain anak dapat belajar mengendalikan emosi, berinteraksi dengan yang lain, memecahkan konflik, dan memperoleh rasa berkemampuan. Melalui bermain, anak juga dapat mengembangkan imajinasi dan kreativitas anak. Oleh karena itu, bermain yang dilakukan oleh anak dan didukung oleh guru merupakan komponen yang esensial dari pembelajaran berorientasi pada perkembangan.

Salah satu permainan tradisional yang ada di Indonesia adalah Benthik. Kata benthik artinya bentur. Benturan tersebut biasanya menghasilkan bunyi "thik". Permainan benthik menggunakan dua alat yang selalu berbenturan dan menimbulkan suara "thik" sehingga dalam bahasa Jawa disebut "benthik". Benturan disini adalah benturan yang terjadi antara kayu-kayu yang saling berbenturan sewaktu bermain. Jadi kata benthik berasal dari suara benturan benda sehingga menimbulkan suara thik.

Permainan ini membutuhkan tempat yang lapang. Permainan benthik ini tidak memandang status sosial dan budaya karena hanya bersifat rekreatif, melatih ketangkasan dan keterampilan. Permainan benthik sudah lama ada dan berasal dari pedesaan. Sampai saat ini permainan benthik ini masih banyak dilakukan anak-anak.

Peralatan yang digunakan berupa dua buah batang kayu yang kuat dan lurus yang disebut dengan benthong yang mempunyai panjang $\pm 40 \mathrm{~cm}$ dan janak dengan panjang $\pm 15 \mathrm{~cm}$. Selain itu, kedua alat tersebut juga diperlukan sebuah lowakan yaitu lubang di tanah untuk tempat meletakkan janak.

- Jumlah Pemain

Satu regu/kelompok bermain 5 orang, baik putra dan putri.

- Alat yang digunakan :

1. Kayu berbentuk bulat (silinder) panjang $45 \mathrm{~cm}$ garis tengah $2 \mathrm{~cm}$. Untuk mencutat, meninting, memukul dan mematok.(benthong)

2. Kayu berbentuk bulat (silinder) dengan ukuran panjang $15 \mathrm{~cm}$, garis tengah 2 $\mathrm{cm}$, alat yang dicutat,ditinting, dipukul, dan dipatok.(janak)

3. Lubang tempat mencutat/mematok, bisa dengan membuat lobang diameter 20 $\mathrm{cm}$ elips atau segitiga atau dengan dua bata/balok berjejer.(lowakan)

- Tempat : Patok lele dimainkan di lapangan terbuka. Bentuk : $90^{\circ}$.

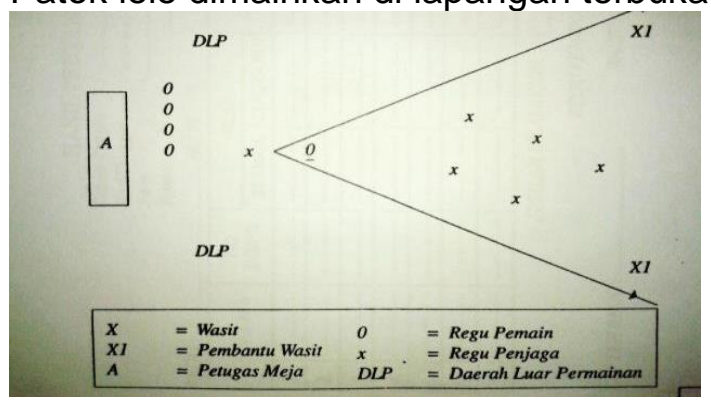


- Jalannya permainan :

1. Undian regu menang penyerang, kalah bertahan.

2. Tahapan permainan :

A) Mencutat :

Janak diletakkan melintang di lubang, dilakukan cutatan ke lapangan. Kemudian janak diletakkan melintang di atas lubang, kemudian di cutat. Jika cutatan tertangkap, maka regu penjaga dapat nilai yang disepakati. Jika tidak tertangkap, janak harus dilemparkan penjaga dan diusahakan mengenai benthong yang dipasang melintang dan jika janak yang dilempar mengenai benthong, maka pemain yang bersangkutan mati. Jika tidak kena dilanjutkan tahap berikutnya. Apabila kena di lakukan pergantian pemain. Nilai dihitung dari jarak janak ke lowakan dengan menggunakan benthong. Jika jarak janak yang dilempar tidak ada satu benthong maka pemain bersangkutan mati.

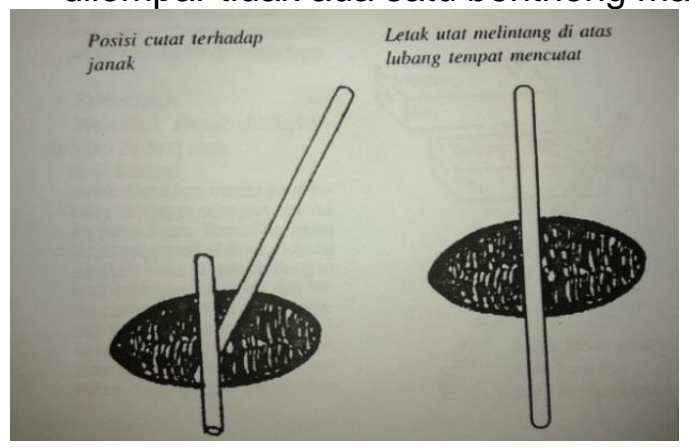

\section{B) Meniting :}

Janak dipegang bersama benthong dengan satu tangan. Selanjutnya janak dilemparkan sedikit ke atas kemudian di pukul. Jika tidak kena dinyatakan mati. Jika janak ditangkap, maka penjaga harus melemparkan dan regu penjaga mendapat nilai. Lalu apabila tidak ditangkap, maka penjaga melemparkan kembali janak tersebut dari tempat janak jatuh ke arah lubang atau tempat mencutat. Apabila kurang dari 1 meter jarak jatuhknya janak ke lubang di katakana mati. Nilai dihitung dari tempat janak setelah dilempar penjaga dengan menggunakan janak ke lowakan

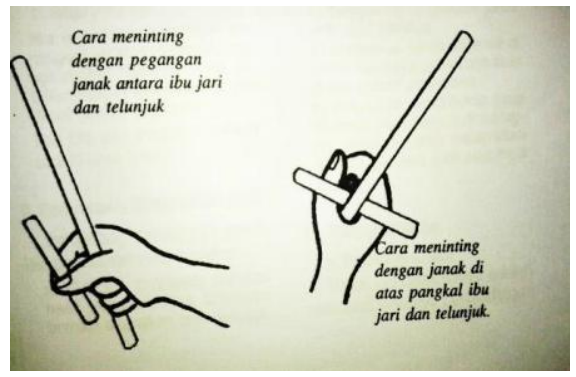

C) Mematok :

Mematok ada 2 cara yaitu di lubang dan di atas batu bata caranya sama yaitu : janak diletakkan membujur di lubang sehingga sebagian muncul ke permukaan. Kemudian janak yang muncul di pukul, dan pemain berusaha meninting janak berulang kali, jumlah tintingan akan dikalikan dengan jarak pukulan. Diusahakan dalam pukulan terakhir sejauh mungkin. Apabila tidak bisa memukul dinyatakan mati. Bila berhasil memukul janak, maka nilai dihitung dari 
jatuhnya janak sampai ke lubang dan seterusnya diulangi lagi dari mencutat, meninting, dan mematok.
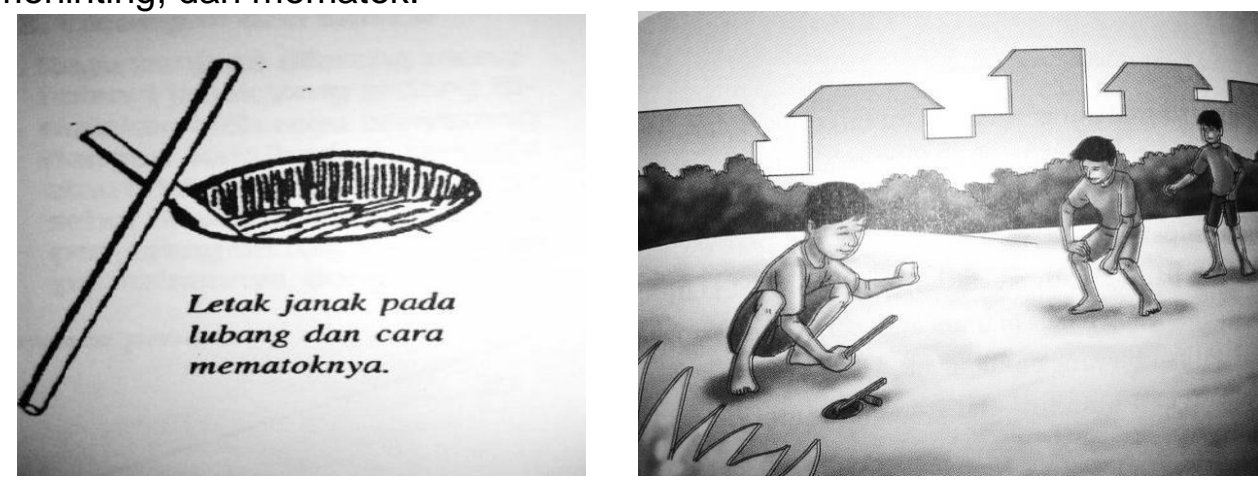

Tabel yang digunakan untuk mencatat skor atau nilai

\begin{tabular}{|l|l|c|c|c|c|}
\hline No & \multicolumn{1}{|c|}{ Regu /nama } & mencutat & meninting & mematok & Jumlah \\
\hline 1 & Amir & 13 & 12 & 20 & 45 \\
\hline 2 & Umar & 10 & 15 & 15 & 40 \\
\hline 3 & $\ldots$ & & & & \\
\hline & \multicolumn{4}{|l}{} \\
\hline
\end{tabular}

\section{KESIMPULAN}

Usia siswa kelas III SD merupakan tahapan usia operasional konkret sehingga dalam pembelajaran masih bersifat nyata. Usia tersebut juga masih pada usia dimana mereka lebih condong atau suka bermain. Dalam pembelajaran matematika guru perlu menerapkan metode ataupun media yang menyenangkan. Dalam pembelajaran matematika operasi penjumlahan pada mata pelajaran matematika guru bisa menggunakan permainan tradisional benthik untuk menarik perhatian siswa. Karena pada permainan benthik pada dasarnya siswa dilatih untuk melakukan operasi hitung penjumlahan.

\section{DAFTAR PUSTAKA}

Andriani, Tuti. 2012. "Permainan Tradisional dalam Membenuk Karakter Anak Usia Dini”. Jurnal Sosial Budaya, Vol. 9, No. 1, Januari-Juli 2012.

Arif S. Sadiman. 2009. Media Pendidikan. Jakarta: Raja Grafindo

Bell, Frederick H. 1981. Teaching and Learning Mathematics (in Secondary School). IOWA : WnC Brown Comp. Publisher

Fosnot, Catherine Twomey \&Maarten Dolk. 2001. Young MATHEMATICIANS AT WORK, Constructing Number Sense, Addition, and Subtraction. United States of America: acid-free paper.

Hartati, S. 2005. Perkembangan Belajar pada Anak Usia Dini. Jakarta : Depdiknas Dirjen Dikti.

Mochtar A. Karim. 1996. Pendidikan Matematika I. Jakarta: Depdikbud

Puskur Balitbang, 2002a. Kurikulum Berbasis Kompetensi untuk Taman Kanak kanak, Sekolah Dasar, dan Sekolah Menengah: kebijakan kurukulum. Jakarta: Pusat Kurikulum Balitbang,Depdiknas.

Santrock. John W. 2007. Perkembangan Anak. Jakarta: Erlangga

Somakim. 2008. Unit 2: Teori Belajar Dienes. In Nyimas Aisyah, dkk. Bahan Ajar Cetak: pengembangan Pembelajaran Matematika Sekolah Dasar, (pp. 2-1 - 242). Direktorat Jenderal Pendidikan Tinggi: Departemen Pendidikan Nasional 
Sri Subarinah. 2006. Inovasi Pembelajaran Matematika SD. Jakarta: Depdiknas

Sujiono, Yuliani Nurani dan Bambang Sujiono. 2010. Bermain Kreatif Berbasis Kecerdasan Jamak. Jakarta: Indeks.

Sukirman, Darmamlya .2008. Permainan tradisional Jawa. Yogyakarta: Kepel Press

W.J.S. Poerwadarminta.1984.Kamus Umum Bahasa Indonesia.Jakarta:PN Balai Pustaka 